\title{
MACEDONIAN NATIONALISM REFRAMED?
}

Review of the book: (Re)konstrukcje narodu: odwieczna Macedonia powstaje w XXI wieku, by Piotr Majewski. (Wydawnictwo Naukowe Katedra, Gdańsk 2013, pp. 490)

n 2009-2010, as a President of the Polish Academy

of Science Scholarship holder, Piotr Majewski, so-

ciologist and theorist of culture, conducted field research in the Republic of Macedonia, which resulted with one of the broadest studies of the current Macedonian nationalism, in general. (Re)konstrukcje narodu... is actually an adapted version of his doctoral work defended in 2012 at Warsaw's Szkoła Wyższa Psychologii Społecznej where he currently works as a teacher. The issues of the nation, nationalism and national identity hold central part of Majewski's scientific interest which also includes topics such as urban anthropology, anthropology of sport, etc.

In his first big scientific publication Majewski offers a comprehensive and well-structured study of the current nationalistic thought(s) and practice(s) in the Republic of Macedonia. The time line of his research covers the period of the first five years of ruling of the right wing/ /nationalistic party VMRO-DPMNE, during which the topics of the Macedonian "nation" and "identity" gained special political and social value. In five selfcontained and yet logically related chapters Majewski builds an interesting anthropological entry on how the issues of the "nation," nationalism, "national identity," history and cultural memory are publicly represented, (re)produced and debated within the Macedonian political and social context. In line with Geertz's (1973) meth-

This is an Open Access article distributed under the terms of the Creative Commons Attribution 3.0 PL License (creativecommons.org/licenses/by/3.0/pl/), which permits redistribution, commercial and non-commercial, provided that the article is properly cited. (C) The Author(s) 2014.

Publisher: Institute of Slavic Studies PAS [Wydawca: Instytut Slawistyki PAN] 
odological instructions, to which this work implicitly refers, Majewski sets his research - descriptive and synchronic in its nature - within the frameworks of a well-defined and elaborated historical and cultural context. This scientific procedure speaks not only about the quality and density of Majewski's knowledge about the subject, but also structures his work in a way that helps the reader to go beyond the synchronicity of the analyzed social facts into the level in which different historical and social contexts coexist and intersect. This level stands as a main reference point for the interpretation of those facts.

In the first chapter of his book, called Tożsamość $i$ inne definicje, Majewski sets the instruments for the scientific inquiry and explains/defines the main concepts which are about to be measured. As the title of the book clearly implies, Majewski borrows the theoretical frameworks for the analysis mainly from the constructivist approach on "nation," "national identity" and nationalism. Building upon Gellner's (1983) and Anderson's (1991) conceptualizations of these issues, Majewski defines them as socially constructed categories, discursively reinforced and reproduced in a certain social context as cultural artifacts of a special kind. Worth mentioning is the fact that Majewski, in line with van Dijk's (2009) theory, treats the discourse not only as an oral/written form in which the social world is reflected, but rather as way of representing/constituting the social reality by the means of various cultural formations: texts, thoughts, but also graphic signs, music, films, monuments, etc. Such broader definition of the discourse in Majewski's work is in accordance with the way how he defines the culture within which the "nation" or "national identity" are articulated and represented. Majewski distances his conceptualization from elite-oriented definition of national culture contained in Gellner's and Anderson's theory and referring to the works of Michael Billig (1995) and Tim Edensor (2002) employs broader definition of the national culture which includes cultural forms deriving from different social strata and means of cultural production. In other words, Majewski's analysis opens itself towards the everyday, popular experiences and representations of the nation and national identity. In this sense, he perceives the national culture as something what Jenkins (2006) defines as convergence or participatory culture, in which the active involvement of "ordinary" people/consumers in the production of the new cultural content relativizes some traditional (canonical) cultural features and forms, as well as the relations between the producers and consumers. In such defined national culture the elites remain most responsible and privileged social actors in the production of the dominant discourses. Still, the other layers of the society are equally important for the maintenance of those discourses in a certain context. In other words, to use de Certeau terminology, Majewski's analysis does not focus only on the discursive strategies employed by the political elites, but expands its frameworks towards the tactics used by the "ordinary" people - the ways how they deal with dominant discourse about the "nation" and "nation identity," what meanings they ascribe to these issues, how they reevaluate and reproduce them in forms of popular, everyday culture.

The book's second chapter called Historia Macedonii i Macedończyków - próba rekonstrukcji stands as a comprehensive introduction into the major topics of the book. In it Majewski deconstructs the most important (both official and unofficial) historical discourses concerning not only what we today know as Republic of Macedonia, but also the historical region of Macedonia-the key point of reference for the dominant nationalistic ideologies in this part of the Balkans. Referring, again implicitly, to the theoretical/methodological tradition of "reading" the history not as a simple continuum of past events and facts, but rather as a socially constructed interpretation of the past (see for example: 
White, 2009), Majewski's reconstruction shows how history is to a great extent nationaloriented and nationalistic in its very essence. Only as such it can serve as an important, "always present" tool of the nationalistic ideology in the process of the discursive naturalization of certain "truths" about the "nation" and "national identity." Parallel to the deconstruction of the dominant historical discourses, Majewski offers his own alternative version of the history of Macedonia. This section, although only indirectly refers to the major topics of the research, organizes the meaning of the rest parts of the book. Also, in my opinion, it represents one of the most important added values of this study.

In the third chapter, Majewski focuses his analysis on the discourses of the official Macedonian historiography from the moment of its institutional establishment - shortly after 1945 - up to nowadays. Again, treating the history as something which is constantly debated, reevaluated and always politically determined, Majewski analysis aims to describe the major shifts in the interpretation of the past that have occurred within the official Macedonian historiography since its beginnings. Referring to Weber's ideal types Majewski distinguishes three actual dominant historical narrations which are in opposition to one another and, of course, serve to different ideological/political centers of power:

1. The narration that follows the logic of the early (socialistic) Macedonian historiography which sees the Macedonian nation rooted in Slavic tribes that came at this part of the Balkans in the $6^{\text {th }}$ century (narration typical for the intellectuals close to the postcommunist opposition);

2. The one to which the author refers as antiquiization, based on the assumption that modern Macedonians are kin-related with their Ancient ancestors such as Alexander the Great or his father Filip II (popular among apologists of ruling nationalistic party);

3. The narration which tends to relate these two strongly opposed versions of the past (typical for the "third-way" intellectuals).

In Majewski's interpretation these narrations represent three most frequent and important lines of argumentation in the on-going (and highly politicized) debate over the question of the modern "Macedonian identity."

The last two chapters of the book Majewski dedicates to the analysis of various cultural formations within which the "Macedonian identity" is currently articulated and reproduced. According to the inclusive definition of the national culture proposed in the opening chapter of the book, the units of analysis in Majewski's study are not only official/institutionalized forms and practices of (re)presenting and performing the national identity, but also unofficial, the bottom-up ways of cultural production which are incorporated in what Edensor calls complex cultural matrix. Such forms of representing "national identity" are becoming crucial tools for providing both: the ideological frames of interpretation of the reality and the group's sense of fixity and steadiness. Their importance for the work of dominant ideology grows with the increasing fluidity of the (national) identity thanks to which all important reference points, traditionally considered as identity's building blocks, are relativized in the global cultural trends (Bauman, 2000). Currently, the most significant ideological "battle ground" where different/ opposed identitarian discourses struggle for symbolic dominance within the Macedonian context is the project Skopje 2014 - one of the main topics of Majewski's analysis. In the last chapter of the book Majewski's analysis focuses on the question how current official and popular culture(s) in Macedonia produce the new national heroes.

(Re)Konstrukcje narodu... undoubtedly represents a serious and comprehensive study of the issues of "nation," nationalism and "national identity" in today's Republic of Ma- 
cedonia and as such it may/should serve as an important reference point for any further research of this topic. Nevertheless, several aspects of Majewski's scientific debut deserve some constructive criticism. First thing towards which I would like to direct my critique is the way in which the theory is related with the process of argumentation in this work. On one hand, Majewski's argumentation occasionally falls into the trap of the broadly defined concepts of national culture and discourse. Hence, the analysis often neglects the fact that the official/institutionalized culture and the everyday/popular culture belong to different levels of social reality, if not to different ontological orders. In this sense, the analysis that will fail to make distinction between these two levels and will treat them as a part of a broadly defined discourse may easily lead to biased interpretations and unwanted generalizations. Hence, few anonymous short-films accidentally found on the YouTube channel, dedicated to President Trajkovski who tragically died in a plane crash, are rather poor argument for the thesis that Macedonian cyber-culture actively uses the figure of dead president in the creation of the new national hero. So called idealization of the figure of the dead president Trajkovski within the elite's discourse, in Majewski's interpretation, has the "nation" as the main reference point. This would be also rather an exaggerated interpretation. The occasional articulation of the images of this kind, in my opinion, has little to do with the intention to create new national hero. Their usage in the public discourse has, (or rather use to have) mainly short-term political goals. (At the moment one could argue without any hesitation that the figure of dead President Trajkovski is forgotten category.) In other words, the sporadic appearance of his "idealized" figure in media space is rather politically than culturally motivated.

On the other hand, the theory in Majewski's work often dominates the interpretation. In some parts of the analysis, the evidence serves the theory to such extent that can easily bring the research to some biased generalizations. In other words, the research's data sample is not organized by the principle of the representatives, but rather it is selected in accordance with the theory which needs to be proven. For example, the interpretation that thanks to the project Skopje 2014 the city square has become the new sacred place for the Macedonian nation is rather arbitrary generalization which does not take into the consideration the fact that the majority of the population in the Republic of Macedonia has exclusively negative attitude towards this project, or shows inferiority towards the symbols and contents of the so-called "antique heritage." 1

Another line of criticism refers to the fact that the analysis fails to offer a thick description of certain phenomena, although it was primarily designed to do that. In the beginning of this review I positively assessed the fact that Majewski's research offers serious diachronic perspective on its main topics. Using this procedure Majewski's work joins the list of what Brubaker (1996, p. 19) has called developmentalist literature on nationalism the one that traces the long-term political, economic and cultural changes that led to the gradual emergence of "nation." Majewski has right when he claims that it was only after 1945 when Macedonian nationalism gained real structural bases to carry out a successful process of constituting "nationally conscious" and relatively uniformed "Macedonian nation." I share Majewski's argument that without formalized social action of the political elites Macedonian nationalism would have no chance to succeed. Yet, in my opinion, somewhere on the way towards the current nationalistic thought(s) and practice(s), Ma-

\section{-.....}

See for example the study conducted by the research team of the Institute of Social Sciences and Humanities from Skopje: http://isshs.edu.mk/documents/1.-Sk2014-ENG.pdf (Institute of social sciences and humanities - Skopje, 2013). 
jewski's analysis, based almost exclusively on the culturalistic definitions of the "nation," neglects (not rejects!) the role and function of the political in the process of so called redefinition/reconstruction of the "nation." In this sense the conclusion (p. 319) that: "[J]ego [projektu Skopje 2014 I.U.] prawdziwym celem jest chęć jakościowej zmiany istoty świata, a więc redefinicji podstawowych elementów macedońskiej tożsamości", is rather insufficient and overlooks important political values and ends this project/process have. One of the possible reasons for such inconsistence in the interpretation may be the problematical operationalization of the category of "nation." Another one may be the fact that Majewski, who rightly conceptualizes the "national identity" as an ideologically-motivated category, offers poor (almost no) theoretical explanation of what ideology is, how it functions, how it frames the reality and narrows the social action towards the ends of special kind. It seems that Anderson's concept of "nation," to which Majewski's analysis continuously refers, is insufficient to grasp the full complexity of the events and social actions described in his work. The concept of imagined communities, although unavoidable in the social analysis of this kind, treats the "nation" as virtually finalized project/cultural construct, neglecting thus both the dynamics of the ideological work behind the process of "imagination" and its political ends. The so-called reconstruction of the "Macedonian identity" has more (if not only) to do with the instability of the ideological/political field in which it occurs than it does with the need of redefining and re-establishing the feeling of belongingness within the group which seeks for new, more potent, forms and means of collective identification and imagination - sacred places, national heroes and myths. Or as Brubaker (1996, p. 17) would rightly put it: "(n)ationalism is not engendered by nations. It is produced-or better, it is induced-by political fields of particular kinds. Its dynamics are governed by the properties of political fields, not by the properties of collectivities."

Please note that I am not claiming that Majewski's analysis employs an essentialist approach that reifies the issues of "nation" and "national identity." 2 That would be and exaggeration far from the truth. What I argue here is that his analysis, accepting the concept of "nation" as a socially constructed cultural artifact, often neglects the political values/meanings this notion carries/emits when it enters the sphere of public usage.

After the dissolution of the communist ideological monopoly, Gruevski was the first Macedonian politician who saw the possibility to seriously intervene in the destabilized ideological field. The conquest of the ideological field went hand in hand with the process of establishing total control over economic, institutional and media resources. What is crucial to be mentioned here is the fact that the "redefinition" of the "Macedonian identity" happened all of a sudden, almost out of nowhere, and with lightning speed engulfed all corners of the Macedonian society. Like never before in the short history of this young "independent" state the notions of "nation" and "national identity" exploded in the public space and discourses releasing such tremendous political power and "heat." The controlled proliferation of the categorizations patriots (for the apologists) and traitors (for the opponents of this new "identity" policy) was a part of Gruevski's well-designed strategy to attain complete political/ideological domination. Hence, in my opinion, the articulation (and the value) of the new forms, narrations and myths concerning the "Mac-

2 Although Majewski is clearly non-essentialist and very well aware of the ideological nature of cultural practices his discourse of 'national identity' is from time to time "infected" by reificatory statements where 'identities' and not human beings or ideologically framed social groups become subjects of action. And hence we read: "Dzięki takim wypowiedziom Macedończycy mogli poczuć się dostrzeżeni jako wyjątkowa wspólnota (...)” (p. 430), or: „[P]o śmierci Proeskiego Macedończycy przeglądali się nie tylko w opowieściach i gestach rodzimych żałobników (...)" (p. 429). 
edonian nation" in the highly politicized and instable context of the Macedonian society is not driven (or determined) by the cultural needs and ends, aimed at establishing new, more solid, more "antique" grounds for the group "identity," but by the needs and rules of the political market. ${ }^{3}$ In this sense, crucial for the maintenance (and popularization) of the new "identity" policy is not the putative solidarity of the group which imagine itself as unique, inherently limited and horizontal comradeship (or imagined family), but rather something what Malešević (2010, p. 11) has called a process of centrifugal ideologization - a massive phenomenon that spreads the systematically controlled ideological message from the center of social organizations to an ever wider strata of the population by the work of the mass media, education institutions, public sphere, governmental agencies (and similar). Obtaining full control over the means of centrifugal ideologization as well as over the economic resources (living the opposition practically empty-handed) Gruevski's regime has been (and still is) successfully managing the process of naturalization of the ideological message. Majewski rightly emphasizes the importance of the work of the socalled banal nationalism for the maintenance of the nationalistic ideology. This claim is in line with Malešević's (p. 194) argument that the long-term potency of nationalist ideology is deeply connected with its almost unconscious, habitual reproduction in the daily rhetoric and practice of politicians, administrators, newspapers, marketing brands, coinage and bank notes, weather reports, but also in the everyday-life "talks" of the "ordinary" people. This last instance, in my opinion, is of great importance for the work of ideology in the highly politicized Macedonian social context. It is so because the notions of "nation" and "national identity," lately have become ideologically-driven categories not only for cultural, but also (if not primarily) political identification. To "be" antique or Slavic Macedonian means to possess (or better to have access to) different political, social (and very often economic) capital. Or otherwise, to be involved in different kind of social action (apologist of opportunist) means to be suddenly framed by different categorizations of "nation" and "national identity." To be more precise, my argument is that Majewski's analysis of current Macedonian nationalism predominated by the culturalistic conceptual frameworks and lacking stabile theoretical grounds for the work of ideology, fails to be something what Brubaker (1996, p. 20) has called "theoretically sophisticated eventful perspective on nationness and nationalism." Such perspective, which will theoretically absorb and explain the sudden politically/ideologically-motivated nationalization of the public and private spaces of social reality, is still needed. Its application would be, for sure, useful in the analysis of some events and on-going trends in Polish society as well.

Majewski's analysis fails to provide good synchronic insight on some other important aspects. One of the most important points of analysis would be the notion of antiquisation. This term undoubtedly holds the central place in the "battle of discourses" well described in this book. Still, the core element of these opposed discourses in Majewski's work remained poorly analyzed and misused. The so called antiquisation represents probably the main discursive weapon in the ideologically-driven criticism of the official's politics of "rebranding" and "reinventing" the "Macedonian identity". In the current Macedonian context the notion of antiquisation has big (although much lower and still decreasing) political value for the opposition's efforts to overcome the symbolical (but also physical) dominance of the ruling nationalistic party. Nevertheless, the creation of this neologism had its own ideological background and its usage in the public discourse has obvious

3 I use here the term "market" in line with Barthes (2000) who sees the (political) mythology as a speech of a special kind, always adapted to a certain types of social consumerism. 
political ends. The important thing is that this notion is naturalized in the opposition's discourse to such extent that its current use often neglects its primary meaning(s). Or as Barthes (2000) would put it, it entered the semiological realm of the political mythology. The role of mythologist, in such case, is to deconstruct the mechanism that activates the naturalization and the usage of such neologisms. Instead of employing this strategy Majewski often uses this notion with the connotations ascribed to it by the critics of the new Macedonian nationalism. Thus, his language often loses the scientific distance and gains rather political meaning - it expresses the author's negative attitude towards the analyzed topic. In this sense, one, after reading several pages of Majewski's book, should understand that its subtitle is not just an innocent stylization but rather conscious ironical locution that carries meanings of not necessarily scientific nature.

Majewski's stake in the theory concerning the issues of "nation," nationalism and "national identity" remains rather poor in his debut. Highly descriptive in its nature, his analysis is subordinated to the existing theoretical frameworks and does not tend to reevaluate or redefine them. However, the importance of Majewski's book grows with the fact that it represents one of the very few systematic attempts which aim to describe current Macedonian nationalistic thought and practice. Therefore, any serious analysis of this topic, especially in the Polish scientific context, should not overlook the insights contained in this book.

\section{BIBLIOGRAPHY}

Anderson, B. (1991). Imagined communities. London: Verso.

Barthes, R. (2000). Mitologie. (A. Dziadek, Trans., K. Kłosiński, Introduction). Warszawa: Wydawnictwo KR.

Bauman, Z. (2000). Liquid modernity. Cambridge: Polity Press.

Billig, M. (1995). Banal nationalism. London: Sage.

Brubaker, R. (1996). Nationalism reframed: Nationhood and the national question in the new Europe. Cambridge: Cambridge University Press.

Certeau, M. de. (1984). The practice of everyday life. Berkeley: University of California Press.

Dijk, T. A. van. (2009). Society and discourse: How social contexts influence text and talk. Cambridge: Cambridge University Press.

Edensor, T. (2002). National identity, popular culture and everyday life. New York: Berg.

Geertz, C. (1973). The interpretation of cultures. New York: Basic Books, Inc.

Gellner, E. (1983). Nations and nationalism. Oxford: Basil Blackwell Publisher Limited.

Institute of social sciences and humanities - Skopje. (2013). Skopje 2014 Project and its effects on the perception of Macedonian identity among the citizens of Skopje. Retrieved July 15, 2014, from http://isshs.edu.mk/documents/1.-Sk2014-ENG.pdf

Jenkins, H. (2006). Convergence culture: Where old and new media collide. New York: University Press.

Majewski, P. (2013). (Re)konstrukcje narodu: odwieczna Macedonia powstaje w XXI wieku. Gdańsk: Wydawnictwo Naukowe Katedra.

Malešević, S. (2010). The sociology of war and violence. Cambridge: Cambridge University Press.

White, H. V. (2009). Proza Historyczna. (R. Borysławski, Trans., E. Domańska, Ed.). Kraków: Universitas. 